\title{
ANALISIS KINERJA KEUANGAN PT SIA SEBELUM DAN SAAT PANDEMI COVID 19
}

\author{
Oktafia Alfi Mufiddah \\ mufiddahokta@gmail.com, Politeknik Keuangan Negara STAN
}

\begin{abstract}
PT SIA is a company engaged in Mechanical and Electrical Contracting. The purpose of this study was to determine the financial performance of PT SIA before and during the Covid-19 pandemic based on liquidity ratios, Solvency ratios, and Profitability ratios. The method used in this research is the interview method, the literature study method, and the data analysis method. The results of the research on financial performance on the liquidity ratio decreased in the current ratio, quick ratio, and cash ratio while the solvency ratio showed an increase in the debt to assets ratio and debt to equity ratio, in addition the profitability ratio showed a decrease in gross profit margin and an increase on the net profit margin and the rate of return on capital. Based on the results of an analysis conducted at PT SIA, the company's financial performance decreased during the Covid-19 pandemic, although the resulting decline was not so significant.
\end{abstract}

Keywords: Financial Report, Financial Performance, Covid 19 Pandemic

\begin{abstract}
Abstrak
PT SIA merupakan perusahaan yang bergerak di bidang Kontraktor Mekanikal dan Elektrikal. Tujuan dari penelitian ini untuk mengetahui performa kinerja keuangan dari PT SIA sebelum dan saat pandemi Covid-19 berdasarkan rasio likuiditas, rasio solvabilitas dan rasio profitabilitas. Metode yang digunakan dalam penelitian ini adalah metode wawancara, metode studi kepustakaan, dan metode analisis data. Hasil penelitian kinerja keuangan pada rasio likuiditas mengalami penurunan di bagian rasio lancar, rasio cepat, dan rasio kas sedangkan rasio solvabilitas menunjukan kenaikan pada bagian rasio utang terhadap aktiva dan rasio utang terhadap modal sendiri, selain itu rasio profitabilitas menunjukan penurunan pada margin laba kotor dan peningkatan pada margin laba bersih dan tingkat pengembalian modal. Berdasarkan hasil analisis yang dilakukan pada PT SIA, kinerja keuangan perusahaan mengalami penurunan saat pandemi Covid-19 meskipun penurunan yang dihasilkan tidak begitu signifikan.
\end{abstract}

Kata kunci: Laporan Keuangan, Kinerja Keuangan, Pandemi Covid 19

\section{PENDAHULUAN}

Sebuah perusahaan pasti memiliki sistem pencatatan untuk mengendalikan kelangsungan kegiatan operasinya. Pencatatan akuntansi meliputi tiga aktivitas dasar yaitu identifikasi, pencatatan, dan pengkomunikasikan peristiwa ekonomi dari sebuah organisasi kepada para pengguna yang berkepentingan (Kieso et al., 2019). Hal ini dilakukan perusahaan demi mencapai tujuannya dalam memperoleh keuntungan dan going concern.

Akuntansi keuangan memuat laporan yang berisi berbagai macam transaksi perusahaan yang melibatkan uang seperti transaksi pembelian dan penjualan maupun kredit. Pelaksanaan akuntansi keuangan dapat digunakan untuk menilai kesuksesan suatu perusahaan. Banyak indikator yang dapat digunakan untuk menilai kesuksesan suatu perusahaan, salah satu indikator yang dapat digunakan adalah laporan keuangan. Laporan keuangan mengambarkan kondisi perusahaan yang sesungguhnya dan berguna bagi pihak internal maupun pihak eksternal.

Kemampuan kinerja suatu perusahaan dapat dinilai melalui analisis rasio keuangan. Dalam melakukan analisis rasio keuangan diperlukan adanya pengetahuan mengenai laporan keuangan secara luas. Ada empat jenis laporan keuangan, antara lain posisi keuangan (neraca), laba-rugi, arus kas, dan perubahan ekuitas. Dengan melakukan analisis rasio keuangan, dapat menentukan kondisi kesehatan perusahaan melalui pos akun di laporan keuangan serta dapat menjadi penilaian pada perusahaan untuk mengetahui posisi perusahaan di kalangan industri sejenis atau lainnya. Dalam pembuatan keputusan pengendalian, rasio keuangan dapat menjadi pertimbangan dan prediksi mengenai hal yang akan dilakukan oleh perusahaan untuk mencapai 


\section{JURNALKU}

Volume 1 No. 1, Maret 2021

tujuannya. Tingkat efisiensi kinerja pada manajer perusahaan dapat ditetapkan dan dituangkan pada catatan atas laporan keuangan dan laporan keuangan.

Terdapat beberapa jenis rasio keuangan yang dibahas penelitian ini yaitu rasio likuiditas, profitabilitas, dan solvabilitas. Apabila terdapat perhitungan hasil yang buruk, perusahaan perlu mewaspadainya sebab bisa saja mengalami kerugian atau kebangkrutan untuk kedepannya. Pandemi COVID-19 mengakibatkan banyak pengaruh pada semua sektor perusahaan di Indonesia, tak terkecuali pada perusahaan yang bergerak pada jasa konstruksi, khususnya kontraktor mekanikal dan elektrikal. Menurut Undang-Undang Republik Indonesia Nomor 18 Tahun 1999 tentang Jasa Konstruksi, jasa konstruksi merupakan salah satu kegitan dalam bidang ekonomi, sosial, dan budaya yang mempunyai peranan penting dalam pencapaian berbagai sasaran guna menunjang terwujudnya tujuan pembangunan nasional.

Pekerjaan kontraktor mekanikal dan elektrikal memang tidak terpengaruh dengan adanya pembatasan sosial. Hal ini berlaku apabila proyek memang sudah berjalan, sedangkan saat ini sangat sulit untuk mendapatkan proyek. Ketersediaan tenaga kerja berupa SDM juga sangat terbatas, terlebih kontraktor elektrikal juga tidak mengestimasikan biaya untuk penanganan COVID-19. Semua serba mendadak dan pendapatan didapatkan seiring dengan adanya proyek berjalan menggunakan prinsip revenue based on project. Prinsip ini membuat kontraktor mengeluarkan dana yang cukup besar diawal dan menjadi lebih besar jika menggunakan dana pihak ketiga.

PT SIA merupakan salah satu perusahaan pada bidang kontraktor elektrikal dan mekanikal yang terkena dampak COVID-19. Oleh karena itu, tertarik untuk melihat dampak pada kinerja keuangan perusahaan sebelum dan saat pandemi COVID-19. Hal ini akan menunjukan seberapa signifikan pengaruh pandemi pada kegiatan operasional perusahaan yang berdampak pada laporan keuangan. Dengan adanya analisis kinerja keuangan berharap dapat menjadi evaluasi bagi sektor kontraktor mekanikal dan elektrikal khususnya PT SIA.

Terdapat penelitian terdahulu yang membahas mengenai cara menganalisis kinerja keuangan melalui analisis likuiditas, profitabilitas, dan solvabilitas sebagaimana yang dilakukan Tumelap (2011). Penelitian terdahulu yang dilakukan oleh Pratiwi et al. (2014) tentang penerapan SAK ETAP pada laporan keuangan PT Nichindo Manado Suisan menemukan bahwa berdasarkan neraca dan laporan laba rugi tahun 2011 dan 2012, menunjukan bahwa perusahaan belum menyajikan laporan perubahan ekuitas, laporan arus kas, dan catatan atas laporan keuangan (CALK) serta terjadi inkonsistensi dalam penyajian beberapa pos pada neraca yang tidak diungkapkan dalam CALK. Pun demikian dengan yang dilakukan Siagian \& Pangemanan (2016) terhadap laporan keuangan Koperasi Karyawan Bank Sulut Go. Perbedaan penelitian meskipun menggunakan dasar SAK ETAP, tetapi berbeda jenis usaha dan dilakukaan di kondisi pandemi covid 19.

Sedangkan penelitian Dewa \& Sitohang (2015) dan Gani \& Putri (2018) terhadap PT Indofood Sukses Makmur sangat jauh berbeda. Di mana terdapat perbedaan standard akuntansi yang digunakan, jenis perusahaan yang terbuka, dan tidak dilakukan di masa pandemi covid 19. Pun demikian yang dilakukan oleh Azizah (2017) terhadap PT Unilever Indonesia dan Maith (2013) terhadap laporan keuangan PT Hanjaya Sampoerna Tbk.

Sementara Shanjaya \& Marlius (2017) lebih kepada tujuan analisis laporan keuangan yang dilakukan oleh PT BPR Batang Kapas kepada calon debiturnya. Sedangkan Santoso et al. (2021) meskipun menggunakan perusahaan jasa konstruksi dan di tengah pandemi covid 19, yang mereka lakukan adalah lebih menganailisa operasional perusahaan, bukan laporan keuangan. Sedangkan Rudiantoro \& Siregar (2012) lebih kepada aspek prospek diterapkannya SAK ETAP terhadap sektor UMKM.

Saat ini, banyak perusahaan yang mengalami kerugian akibat pandemi. Hal tersebut disebabkan oleh menurunnya penjualan secara drastis, kesulitan dalam mendapatkan 


\section{JURNALKU}

Volume 1 No. 1, Maret 2021

persediaan, serta kurs yang tidak stabil. Fenomena ini membuat dampak yang cukup besar terhadap kinerja keuangan perusahaan. Tujuan penelitian adalah untuk menganalisis kinerja keuangan PT SIA sebelum dan saat pademi COVID-19 dan untuk menganalisis upaya yang dilakukan dalam mengatasi penyebab masalah dari faktor internal dan eksternal PT SIA.

\section{KAJIAN TEORI \\ Laporan Keuangan}

Laporan Keuangan bagi perusahaan merupakan hal wajib yang harus dilakukan untuk memuat berbagai informasi mengenai segala kegiatan perusahaan yang berhubungan dengan keuangan maupun informasi tambahan terkait. Hal ini menujukan bahwa laporan keuangan sangat dibutuhkan dalam kegiatan evaluasi di akhir periode dan acuan yang menggambarkan kinerja perusahaan pada satu periode. Proses pembuatan laporan keuangan tidak dapat diabaikan pada setiap detailnya.

Mengkomunikasikan antara data keuangan maupun aktivitas pada perusahaan dengan pihak yang berkepentingan agar dapat dipahami sebagai hasil dari sebuah proses akuntansi merupakan pengertian dari laporan keuangan. Berikut beberapa pengertian laporan keuangan yang disajikan baik menurut PSAK (Pernyataan Standar Akuntansi Keuangan) maupun pendapat organisasi dan para ahli.

Menurut Ikatan Akuntan Indonesia (2012), pengertian laporan keuangan adalah menyajikan struktur posisi keuangan dan kinerja keuangan dalam sebuah entitas. Dalam kepentingan umum laporan keuangan memiliki tujuan sebagai penyajian informasi mengenai posisi keuangan (financial position), kinerja keuangan (financial performance), dan arus kas (cash flow) dari entitas yang berguna dalam membuat keputusan ekonomis para penggunanya. Dalam mencapai tujuan ini, informasi laporan keuangan menyediakan elemen dari entitas yang terdiri dari aset, kewajiban, networth, beban, dan pendapatan (termasuk gain dan loss), perubahan ekuitas dan arus kas. Informasi tersebut diikuti dengan catatan, akan membantu pengguna memprediksi arus kas masa depan.

Menurut Kieso et al. (2019), laporan keuangan merupakan sarana yang dapat digunakan oleh entitas untuk mengkomunikasikan keadaan mengenai kondisi keuangannya kepada pihakpihak yang berkepentingan baik yang berasal dari internal entitas maupun eksternal entitas. Kasmir (2014) mendefinisikan laporan keuangan sebagai laporan yang menunjukkan kondisi keuangan perusahaan pada saat ini atau dalam suatu periode tertentu. Menurut Harahap (2010), laporan keuangan menggambarkan kondisi keuangan dan hasil usaha suatu perusahaan pada saat tertentu atau jangka waktu tertentu. Adapun jenis laporan keuangan yang lazim dikenal adalah neraca, laporan laba-rugi atau hasil usaha, laporan perubahan ekuitas, laporan arus kas, dan laporan posisi keuangan.

Menurut Ikatan Akuntan Indonesia (2012), laporan keuangan memiliki tujuan sebagai berikut berdasarkan Standar Akuntansi Keuangan, yaitu (1) Menyediakan informasi yang menyangkut mengenai posisi keuangan, kinerja, serta suatu perubahan posisi keuangan pada suatu perusahaan. Semua hal yang bermanfaat bagi sejumlah besar pengguna dalam menentukan keputusan ekonomi. (2) Dalam menyusun laporan keuangan dengan tujuan memenuhi kebutuhan bersama bagi sebagian besar pemakai, laporan keuangan tidak selalu menyediakan semua informasi yang mungkin dibutuhkan pemakainya dalam mengambil keputusan ekonomi. Hal ini disebabkan laporan keuangan yang secara umum menggambarkan pengaruh keuangan dan kejadian di masa lalu. (3) Laporan keuangan menunjukan kegiatan yang telah dilakukan manajemen (stewardship) maupun pertanggungjawaban manajemen mengenai sumber daya (karyawan) yang diberi tugas dan dipercayakan kepadanya.

Menurut Munawir (2010), laporan keuangan memiliki keterbatasan, yaitu (1) Pada dasarnya laporan keuangan yang dibuat secara periodik merupakan laporan yang dibuat dalam 


\section{JURNALKU}

Volume 1 No. 1, Maret 2021

waktu tertentu dan bersifat sementara (interim report) yang bukan merupakan hasil laporan final. (2) Laporan keuangan menampilkan angka dalam rupiah yang dianggap bersifat tepat dan pasti, akan tetapi dalam penyusunannya dengan standar nilai pada laporan keuangan mungkin dapat terjadi perubahan maupun perbedaan. (3) Penyusunan laporan keuangan berdasarkan hasil pencatatan transaksi keuangan yang bernilai rupiah dari berbagai waktu atau tanggal yang lalu. (4) Berbagai faktor yang dapat mempengaruhi posisi atau keadaan pada keuangan perusahaan yang tidak dinyatakan dalam satuan uang belum tersaji secara sempurna pada laporan keuangan.

Pengertian Cash Basic Accounting Method (metode akuntansi dasar kas) adalah sebuah metode akuntansi yang pengakuan biaya/pendapatan akan dicatat saat dibayar/diterima tanpa menghubungkan dengan kapan biaya/pendapatan itu terjadi (Ardiyos, 2008). Selain itu, ada sistem akuntansi yang mengakui pendapatan saat uangnya sudah dibayar/diterima yang disebut dengan accrual basis accounting.

Definisi accrual basis accounting menurut Ardiyos (2008) adalah suatu metode akuntansi yang mencatat/mengakui beban maupun pendapatan saat terjadinya (beban dicatat saat barang/jasa diterima sedang pendapatan dicatat pada saat barang/jasa diserahkan tanpa menghiraukan saat pengeluaran maupun penerimaan dari pihak yang bersangkutan.

Ikatan Akuntan Iindonesia (2012) mewajibkan untuk menyusun laporan keuangan bagi entitas. Entitas yang menggunakan dasar akrual tidak diwajibkan membuat laporan arus kas. Berkaitan dengan ini diatur dalam SAK ETAP paragraf 2.33. dalam dasar akrual, pos-pos diakui sebagai aset, kewajiban, ekuitas, penghasilan, dan beban (unsur-unsur laporan keuangan ketika definisi dan kriteria pengakuan pada pos-pos tersebut terpenuhi).

\section{SAK ETAP}

Menurut Wuwungan (2016), SAK (Standar Akuntansi Keuangan) adalah suatu kerangka prosedur dalam pembuatan laporan keuangan untuk mejadikan penyajian laporan keuangan secara seragam. Berikut beberapa entitas yang diijinkan untuk menggunakan SAK ETAP, yaitu (1) Suatu entitas yang tidak memiliki akuntabilitas publik yang signifikan. (2) Entitas yang menerbitkan laporan keuangan dengan tujuan umum (general purpose financial statement) untuk pengguna eksternal. Contoh pengguna eksternal adalah dalam pengelolaan usaha pemilik tidak terlibat langsung, kreditur dan lembaga pemeringkat kredit lainnya.

\section{Analisis Kinerja Keuangan}

Analisis kinerja keuangan adalah suatu usaha formal yang dilakukan perusahaan dalam mengevaluasi efisien dan efektivitas dari aktivitas yang dilakukan perusahaan pada periode tertentu. Menurut Munawir (2010), kinerja keuangan perusahaan merupakan salah satu dasar mengenai penilaian kondisi keuangan perusahaan. Menurut Subramanyam dan Wild (2010), kinerja keuangan merupakan pengakuan pendapatan dan pengaitan biaya dan menghasilkan laba yang lebih unggul dibandingkan denga arus kas dalam mengevaluasi kinerja keuangan. Menurut Jumingan (2009), kinerja keuangan merupakan gambaran kondisi mengenai keuangan pada periode yang menyangkut mengenai aspek penghimpunan dana maupun penyaluran dana yang dapat diukur menggunakan indicator kecukupan modal, likuiditas, dan profitabilitas. Menurut Fahmi (2012), kinerja keuangan merupakan analisis yang dilakukan untuk melihat perusahaan mengenai bagaimana pelaksanaan usaha dengan menggunakan aturan pelaksanaan keuangan yang baik dan benar seperti yang diatur pada Standar Akuntansi Keuangan (SAK) ataupun Generally Accounting Principles (GAAP).

Menurut Jumingan (2009) tujuan penilaian kinerja keuangan yaitu (1) Untuk mengetahui keberhasilan pada pengelolaan keuangan perusahaan terutama kondisi likuiditas, kecukupan modal, dan profitabilitas yang di capai dalam tahun berjalan maupun pada tahun sebelumnya. (2) Untuk mengetahui kemampuan perusahaan dalam mengelola dan menggunakan semua asetnya untuk menghasilakan profit secara efisien. 
Manfaat pengukuran kinerja keuangan menurut Mulyadi (2009) bagi manajemen adalah (1) Untuk mengelola operasi secara efektif dan efisien melalui pemotivasian karyawan secara umum. (2) Untuk mengidentifikasi kebutuhan dalam pelatihan dan pengembangan karyawan serta untuk memfasilitasi kriteria dalam seleksi dan evaluasi program pelatihan pada karyawan. (3) Untuk menyediakan umpan balik bagi karyawan mengenai penilaian kinerja mereka dari atasan.

\section{Analisis Laporan Keuangan}

Analisis laporan keuangan merupakan teknik analisis yang menggunakan metode untuk menghasilkan keputusan yang tepat terkait tindakan yang akan diambil. Pihak stakeholder seperti investor, kreditur, konsultan keuangan, pemerintah dan pihak manajemen internal. Menurut Harahap (2010), analisis laporan keuangan menguraikan pos-pos laporan keuangan untuk dijadikan menjadi unit informasi yang lebih kecil serta melihat hubungannya yang bersifat signifikan atau memiliki makna antara satu dengan yang lain baik antara data kuantitatif maupun non-kuantitatif yang memiliki tujuan untuk mengetahui kondisi keuangan secara mendalam dan sangat penting untuk proses menghasilkan keputusan yang akan diambil. Menurut Harjito \& Martono (2011), analisis laporan keuangan merupakan analisis yang dilakukan mengenai kondisi keuangan suatu perusahaan yang melibatkan laporan keuangan seperti neraca dan laba rugi.

\section{Analisis Rasio Keuangan}

Menurut Kasmir (2014), rasio keuangan merupakan kegiatan untuk membandingkan angak-angka di dalam laporan keuangan dengan cara membagi satu angka dengan angka yang lainnya. Komponen yang dibandingkan dapat dilakukan antara satu komponen dengan komponen dalam satu laporan keuangan maupun antar komponen yang ada diantara laporan keuangan. Menurut Harjito \& Martono (2011), menggunakan cara membandingkan rasio keuangan perusahaan dari tahun ke tahun akan membuat seorang analis dapat perubahan komposisi yang terjadi dan menentukan apakah terdapat kenaikan maupun penurunan pada kondisi keuangan maupun kinerja keuangan dalam kurun waktu tersebut. Berdasarkan laporan keuangan yang dianalisis, analisis rasio keuangan dapat dibedakan menjadi 2 yaitu (1) Analisis individual, analisis ini dilakukan pada unsur-unsur yang ada pada salah satu laporan keuangan. Salah satu contoh analisis individual misalnya analisis rasio untuk unsur-unsur yang ada pada laporan neraca saja atau laporan laba rugi saja. (2) Analisis silang, analisis ini melibatkan unsurunsur yang ada pada laporan neraca dan sekaligus unsur-unsur yang berada pada laporan laba rugi.

\section{METODE}

Pengumpulan data yang digunakan menggunakan data primer dan data sekunder melalui metode wawancara yang dilakukan dengan cara memperoleh informasi langsung mengenai kegiatan internal perusahaan menggunakan tanya jawab secara langsung terhadap karyawan yang bertugas dan bertanggung jawab atas penyusunan laporan keuangan PT SIA. Maka dari itu didapatkan informasi yang aktual untuk digunakan sebagai data. Metode studi kepustakaan dilakukan dengan mencari referensi dari sumber yang relevan dengan topik yang dibahas. Sumber data tersebut dapat diperoleh dari buku, jurnal ilmiah, laporan keuangan, website, dan sumber lainnya yang terkait dengan analisis kinerja keuangan perusahaan. Metode analisis data dilakukan dengan cara mengolah data yang telah didapatkan dari laporan keuangan perusahaan dan sumber terkait lainnya untuk penelitian ini. Laporan keuangan tahun 2019 dan 2020 menjadi sumber utama untuk dianalisis, khususnya laporan laba rugi dan neraca yang dianalisis dengan menggunakan rasio keuangan. Dengan demikian hasil dari perhitungan rasio keuangan diteliti dan dibandingkan serta dihubungkan satu dengan yang lain sehingga didapatkan kesimpulan penelitian yang dilakukan mengenai dampak pandemi COVID-19. 


\section{HASIL DAN PEMBAHASAN Deskripsi Objek Penelitian}

Data Keuangan PT SIA akan digunakan sebagai dasar untuk menganalisis rasio-rasio keuangan. Laporan keuangan yang akan digunakan ialah laporan laba-rugi dan laporan posisi keuangan (neraca) dari tahun 2019 sampai dengan tahun 2020. Laporan tersebut menjadi sangat relevan karena pandemi yang terjadi dimulai pada tahun 2020. Hal ini dapat digunakan sebagai pembanding untuk menganalisa kinerja keuangan PT SIA sebelum dan saat pandemi covid-19. Data laporan keuangan diperoleh dari pihak manajemen PT SIA secara langsung. Perusahaan menggunakan dasar pengukuran pada laporan keuangan meggunakan konsep biaya perolehan (historical cost). Selain itu, laporan keuangan disusun dengan metode akrual kecuali laporan kas atau arus kas. Laporan arus kas disusun dengan menggunakan metode tidak langsung (indirect method) yang di klasifikasikan dalam aktivitas operasi, investasi dan pendanaan. Pembukuan perusahaan diselenggarakan dalam mata uang rupiah.

Laporan keuangan 2019 dan 2020 yang disajikan dalam segmen ini adalah laporan keuangan dengan opini wajar dan telah sesuai dengan Standar Akuntansi Keuangan Entitas Tanpa Akuntabilitas Publik (SAK ETAP) menurut KAP Jeptha Nasib \& Junihol. Laporan Keuangan 2019 dan 2020 baru selesai teraudited pada bulan April 2021. Laporan laba rugi pada PT SIA dilaporkan menggunakan ketentuan SAK ETAP yang informasinya terbatas. Pendapatan proyek diakui berdasarkan jumlah pengakuan yang telah digunakan berdasarkan tingkat kemajuan proyek yang telah dicapai atau menganut metode presentase penyelesaian. Beban pokok proyek merupakan beban proyek yang telah digunakan pengakuannya. Sehingga pada pendapatan trading diakui pada saat barang diserahkan kepada pembeli dan beban diakui sesuai dengan masa manfaat (accrual basis) pada periode bersangkutan. Kebanyakan proyek yang didapat PT SIA selesai pada tahun 2020. Hal ini menyebabkan pengakuan pendapatan banyak diakui pada tahun 2020.

Laporan yang di buat PT SIA disusun dan dipergunakan hanya untuk mengikuti tender dan tidak untuk digunakan kepentingan dan keperluan lain. PT SIA juga menggunakan laporan laba rugi unaudited untuk pelaporan pajaknya. Hal ini membuat pihak manajemen bekerja dua kali dalam penyusunan laba ruginya. Selain itu, pengelompokan beban yang dilakukan oleh pihak manajemen dengan KAP pengaudit juga berbeda. Sehingga terdapat beberapa nominal yang berbeda dalam pelaporannya.

Tabel 1 Laporan Laba Rugi PT SIA

\begin{tabular}{|l|r|r|r|}
\hline \multicolumn{1}{|c|}{ Keterangan } & \multicolumn{1}{c|}{$\mathbf{2 0 1 8}$} & \multicolumn{1}{c|}{$\mathbf{2 0 1 9}$} & \multicolumn{1}{c|}{$\mathbf{2 0 2 0}$} \\
\hline PENDAPATAN & 6.876 .680 .044 & 5.295 .464 .521 & 8.974 .326 .776 \\
\hline Beban Operasional & 4.177 .092 .500 & 3.079 .708 .683 & 5.748 .930 .900 \\
\hline Laba (Rugi) Kotor & $\mathbf{2 . 6 9 9 . 5 8 7 . 5 4 4}$ & $\mathbf{2 . 2 1 5 . 7 5 5 . 8 3 8}$ & $\mathbf{3 . 2 2 5 . 3 9 5 . 8 7 6}$ \\
\hline Beban Admisnistrasi dan Umum & 1.731 .140 .000 & 1.407 .550 .700 & 1.770 .975 .000 \\
\hline Jumlah Beban Usaha & $\mathbf{1 . 7 3 1 . 1 4 0 . 0 0 0}$ & $\mathbf{1 . 4 0 7 . 5 5 0 . 7 0 0}$ & $\mathbf{1 . 7 7 0 . 9 7 5 . 0 0 0}$ \\
\hline Laba (Rugi) Usaha & $\mathbf{9 6 8 . 4 4 7 . 5 4 4}$ & $\mathbf{8 0 8 . 2 0 5 . 1 3 8}$ & $\mathbf{1 . 4 5 4 . 4 2 0 . 8 7 6}$ \\
\hline Pendapatan (beban) Lain Lain & 3.130 .342 & $(239.680 .215)$ & $\mathbf{2} 296.434 .437)$ \\
\hline Laba Bersih Sebelum Pajak & $\mathbf{9 7 1 . 5 7 7 . 8 8 6}$ & $\mathbf{5 6 8 . 5 2 4 . 9 2 3}$ & $\mathbf{1 . 1 5 7 . 9 8 6 . 4 3 9}$ \\
\hline Pajak Final & 137.663 .943 & 105.909 .290 & 269.229 .803 \\
\hline Laba Bersih & $\mathbf{8 3 3 . 9 1 3 . 9 4 3}$ & $\mathbf{4 6 2 . 6 1 5 . 6 3 3}$ & $\mathbf{8 8 8 . 7 5 6 . 6 3 6}$ \\
\hline
\end{tabular}

Sumber: Diolah dari Laporan Keuangan PT SIA 


\section{JURNALKU}

Volume 1 No. 1, Maret 2021

PT SIA selalu menggunakan transaksi dengan mata uang rupiah dalam usahanya. Apabila ada transaksi dengan mata uang asing akan dijabarkan dalam mata uang rupiah dengan menggunakan kurs yang berlaku pada tanggal transaksi. Pada tanggal neraca, aset dan kewajiban dalam mata uang asing dijabarkan dalam rupiah berdasarkan kurs tengah Bank Indonesia yang berlaku pada tanggal tersebut.

Akun kas dan setara kas meliputi kas, simpanan yang sewaktu-waktu bisa dicairkan, dan investasi likuid jangka pendek lainnya dengan jangka waktu jatuh tempo tiga bulan atau kurang. Pihak manajemen berkeyakinan bahwa seluruh piutang perusahaan akan dapat diterima sesuai dengan tanggal jatuh temponya dan menjamin tidak ada piutang yang macet. Selanjutnya, untuk akun persediaan dicatat berdasarkan metode bruto dan penilaian atas persediaan didasarkan pada harga perolehan dengan metode FIFO.

Aset tetap dinyatakan dengan harga perolehan setelah dikurangi akumulasi penyusutan yang dilakukan dengan metode garis lurus selama masa manfaat aset tetap. Pengeluaran untuk pemeliharaan dan perbaikan yang dilakukan diakui sebagai beban pada saat timbulnya beban tersebut. Pengeluaran yang bersangkutan akan dikapitalisasi saat menabah umur manfaat asset. Harga perolehan dan akumulasi penyusutan aset tetap yang dijual atau dihapuskan dikeluarkan dari nilai buku pada saat penjualan atau penghapusan, keuntungan atau kerugian yang dihasilkan dibebankan pada laba rugi tahun berjalan.

Tabel 2 Laporan Posisi Keuangan (Neraca) PT SIA

\begin{tabular}{|l|r|r|}
\hline Keterangan & $\mathbf{2 0 1 9}$ & $\mathbf{2 0 2 0}$ \\
\hline ASET & & \\
\hline ASET LANCAR & 1.085 .400 .400 & 1.123 .760 .861 \\
\hline Kas Setara Kas & 2.351 .693 .385 & 3.299 .013 .100 \\
\hline Piutang & 964.670 .000 & 1.425 .360 .000 \\
\hline Persediaan & 157.448 .188 & 152.776 .465 \\
\hline Biaya Dibayar Dimuka & 21.916 .817 & - \\
\hline Pajak Dibayar Dimuka & $\mathbf{4 . 5 8 1 . 1 2 8 . 7 9 0}$ & $\mathbf{6 . 0 0 0 . 9 1 0 . 4 2 6}$ \\
\hline Jumlah Aset Lancar & & \\
\hline ASET TIDAK LANCAR & 1.122 .612 .500 & 1.267 .487 .500 \\
\hline Aset Tetap & $\mathbf{1 . 1 2 2 . 6 1 2 . 5 0 0}$ & $\mathbf{1 . 2 6 7 . 4 8 7 . 5 0 0}$ \\
\hline Jumlah Aset Tidak Lancar & $\mathbf{5 . 7 0 3 . 7 4 1 . 2 9 0}$ & $\mathbf{7 . 2 6 8 . 3 9 7 . 9 2 6}$ \\
\hline JUMLAH ASET & & \\
\hline LIABILITAS DAN EKUITAS & & \\
\hline LIABILITAS LANCAR & 17.600 .000 & - \\
\hline Hutang Usaha & 2.000 .000 .000 & 2.700 .000 .000 \\
\hline Hutang Bank & 6.500 .000 & - \\
\hline Biaya YMH Dibayar & $\mathbf{2 . 0 2 4 . 1 0 0 . 0 0 0}$ & $\mathbf{2 . 7 0 0 . 0 0 0 . 0 0 0}$ \\
\hline Jumlah Liabilitas Lancar & & \\
\hline EKUITAS & 1.200 .000 .000 & 1.200 .000 .000 \\
\hline Modal Disetor & 2.017 .025 .657 & 2.479 .641 .290 \\
\hline Laba Rugi Ditahan & 462.615 .633 & 888.756 .636 \\
\hline Laba Rugi Tahun Berjalan & $\mathbf{3 . 6 7 9 . 6 4 1 . 2 9 0}$ & $\mathbf{4 . 5 6 8 . 3 9 7 . 9 2 6}$ \\
\hline Jumlah Ekuitas & $\mathbf{5 . 7 0 3 . 7 4 1 . 2 9 0}$ & $\mathbf{7 . 2 6 8 . 3 9 7 . 9 2 6}$ \\
\hline JUMLAH LIABILITAS DAN EKUITAS
\end{tabular}

Pembahasan

Sumber: Diolah dari Laporan Keuangan PT SIA

\section{Analisis Rasio Likuiditas Tahun 2019 dan 2020}

Rasio Lancar (Current Ratio)

Dalam menganalisis rasio lancar pada PT SIA menggunakan perhitungan dari aset lancar dibagi dengan kewajiban lancar. Pada analisis rasio ini dapat mengukur kemampuan PT SIA dalam memenuhi atau membayar utang lancar yang akan jatuh tempo. 
Tabel 3 Rasio Lancar PT SIA 2019-2020

\begin{tabular}{|l|r|r|}
\hline \multicolumn{1}{|c|}{ Keterangan } & 2019 & 2020 \\
\hline Aset Lancar & 4.581 .128 .790 & 6.000 .910 .426 \\
\hline Kewajiban Lancar & 2.024 .100 .000 & 2.700 .000 .000 \\
\hline Rasio Lancar & $226 \%$ & $222 \%$ \\
\hline
\end{tabular}

Sumber: Diolah dari laporan keuangan PT SIA

Pada tabel 3 rasio lancar PT SIA tahun 2019 didapatkan hasil sebesar 226\%, yang berarti setiap Rp1 kewajiban lancar dijamin perusahaan dengan Rp2,26 aset lancar. Maka dari itu, diperoleh perbandingan antara aset lancar dan kewajiban lancar sebesar 2,26:1. Pada tahun 2020 rasio lancar PT SIA sebesar 222\%, yang berarti setiap Rp1 kewajiban lancar dijamin perusahaan dengan Rp2,22 aset lancar. Sehingga diperoleh perbandingan antara aset lancar dan kewajiban lancar sebesar 2,22:1. Berdasarkan hasil perhitungan rasio lancar pada tahun 2019-2020, PT SIA mengalami penurunan dalam rasio lancarnya yaitu sebesar $4 \%$ yaitu dari $2,26 \%$ menjadi $2,22 \%$. Hal ini berarti perusahaan mengalami penurunan kemampuan dalam membayar utang lancarnya, disebabkan perusahaan melakukan penambahan jumlah kewajiban lancarnya. Akan tetapi rasio menunjukan hasil di atas $100 \%$ yang mana masih dinilai dalam batas wajar dan perusahaan masih bisa dikatakan sehat. Oleh karena itu, PT SIA masih mampu untuk membayar seluruh kewajiban lancarnya dengan aset lancarnya apabila ditagih secara keseluruhan.

Rasio Cepat (Quick Ratio)

Dalam menganalisis rasio cepat PT SIA menggunakan perhitungan aset lancar dikurangi dengan persediaan lalu dibagi dengan kewajiban lancar. Analisis rasio ini dapat mengukur kemampuan PT SIA dalam memenuhi atau membayar utang lancar yang akan jatuh tempo tanpa memperhitungkan nilai persediaan.

Tabel 4 Rasio Cepat PT SIA 2019-2020

\begin{tabular}{|l|r|r|}
\hline Keterangan & 2019 & 2020 \\
\hline Aset Lancar - Persediaan & 3.616 .458 .790 & 4.575 .550 .426 \\
\hline Kewajiban Lancar & 2.024 .100 .000 & 2.700 .000 .000 \\
\hline Rasio Cepat (Quick Ratio) & $179 \%$ & $169 \%$ \\
\hline
\end{tabular}

Sumber: Diolah dari Laporan Keuangan PT SIA

Pada perhitungan tabel 4 rasio cepat PT SIA tahun 2019 didapatkan hasil sebesar 179\%, yang berarti setiap Rp1 kewajiban lancar dijamin perusahaan dengan Rp1,79 aset lancar tanpa persediaan. Maka dari itu, diperoleh perbandingan antara aset lancar tanpa persediaan dan kewajiban lancar sebesar 1,79:1. Pada tahun 2020 rasio cepat PT SIA sebesar 169\%, yang berarti setiap Rp1 kewajiban lancar dijamin perusahaan dengan Rp1,69 aset lancar tanpa persediaan. Maka dari itu, diperoleh perbandingan antara aset lancar tanpa persediaan dan kewajiban lancar sebesar 1,69:1. Berdasarkan hasil perhitungan rasio cepat pada tahun 20192020, PT SIA mengalami penurunan seperti pada rasio lancarnya yaitu sebesar $10 \%$ dari $1,79 \%$ menjadi $1,69 \%$. Hal ini berarti perusahaan juga mengalami penurunan kemampuan dalam membayar utang lancarnya, yang mana tidak beda jauh dengan rasio lancarnya bahwa PT SIA masih mampu untuk membayar seluruh kewajiban lancarnya dengan aset lancarnya meskipun tanpa persediaan apabila ditagih secara keseluruhan.

Rasio Kas (Cash Ratio)

Dalam menganalisis rasio kas pada PT SIA menggunakan perhitungan kas dan setara kas dibagi dengan kewajiban lancar. Pada analisis rasio ini dapat mengukur ketersediaan uang kas PT SIA dalam memenuhi atau membayar utang lancar yang akan jatuh tempo. 
Tabel 5 Rasio Kas PT SIA 2019-2020

\begin{tabular}{|l|r|r|}
\hline Keterangan & 2019 & 2020 \\
\hline Kas dan Setara Kas & 1.085 .400 .400 & 1.123 .760 .861 \\
\hline Kewajiban Lancar & 2.024 .100 .000 & 2.700 .000 .000 \\
\hline Rasio Kas (Cash Ratio) & $54 \%$ & $42 \%$ \\
\hline
\end{tabular}

Sumber: Diolah dari Laporan Keuangan PT SIA

Hasil perhitungan tabel 5 mengenai rasio kas tahun 2019 PT SIA sebesar 54\%, yang berarti setiap Rp1 kewajiban lancar dijamin dengan Rp0,54 kas dan setara kas pada perusahaan. Sehingga memiliki perbandingan sebesar 0,54:1 pada kas dan setara kas dengan kewajiban lancarnya. Pada tahun 2020 rasio kas PT SIA sebesar 42\%, yang berarti setiap Rp1 kewajiban lancar dijamin dengan Rp0,42 kas dan setara kas pada perusahaan. Sehingga memiliki perbandingan sebesar 0,42:1 pada kas dan setara kas dengan kewajiban lancarnya. Rasio kas yang didapat pada perhitungan menunjukan bahwa rasio kas PT SIA dalam kondisi kurang baik karena angka yang didapat bernilai kurang dari 100\%. Kondisi ini mengindikasikan bahwa perusahaan memiliki tindakan manajemen yang kurang terhadap ketersediaan kasnya.

Rasio kas PT SIA mengalami penurunan sebesar 12\% dari 54\% pada tahun 2019 menjadi $42 \%$ pada tahun 2020. Saat dibandingkan dengan rasio lancar dan cepat, rasio kas PT SIA mengalami perbedaan dimana perusahaan harus menggunakan sumber aset lancar lainnya dalam memenuhi utang lancarnya saat ditagih secara keseluruhan. Nilai aset lancar pada PT SIA didominasi oleh piutang yang dapat dicairkan setelah pengerjaan proyek selesai.

Rasio Perputaran Kas (Cash Turnover Ratio)

Dalam menganalisis rasio perputaran kas pada PT SIA menggunakan perhitungan pendapatan bagi dengan modal kerja. Nilai modal kerja didapat dari aktiva lancar dikurangi dengan kewajiban lancar. Pada analisis rasio ini dapat mengukur tingkat kecukupan modal kerja PT SIA yang dibutuhkan dalam memenuhi atau membayar tagihan penjualan.

Tabel 6 Rasio Perputaran Kas PT SIA 2019-2020

\begin{tabular}{|l|r|r|}
\hline Keterangan & \multicolumn{1}{|c|}{2019} & 2020 \\
\hline Penjualan(Pendapatan) & 5.295 .464 .521 & 8.974 .326 .776 \\
\hline Modal Kerja & 2.557 .028 .790 & 3.300 .910 .426 \\
\hline Rasio Perputaran Kas & $207 \%$ & $272 \%$ \\
\hline
\end{tabular}

Sumber: Diolah dari Laporan Keuangan PT SIA

Berdasarkan hasil perhitungan tabel 6, rasio perputaran kas PT SIA menunjukan di atas $100 \%$ yang menunjukan bahwa semakin efisien PT SIA dalam penggunaan kasnya. Hasil perhitungan rasio ini berbanding terbalik dengan rasio kas yang dimiliki perusahaan yang bisa dibilang rendah. PT SIA mengalami kenaikan rasio perputaran kas dari tahun 2019-2020 sebesar 65\% yaitu pada tahun 2019 sebesar 207\% dan tahun 2020 menjadi 272\%. Dari hal ini, nilai rasio perputaran kas PT SIA dapat digolongkan sebagai tinggi dan sudah memenuhi standar industri yang mengharuskan rasio perputaran kas sebanyak 10 kali.

\section{Analisis Rasio Solvabilitas Tahun 2019 dan 2020}

Rasio Utang terhadap Aktiva (Debt to Assets Ratio)

Dalam menganalisis rasio utang terhadap aktiva pada PT SIA menggunakan perhitungan total kewajiban dibagi dengan total aktiva/aset. Pada analisis rasio ini dapat mengukur besarnya aktiva yang dibiayai oleh kreditur. Semakin tinggi hasil perhitungan debt ratio, maka jumlah modal pinjaman yang digunakan untuk memperoleh keuntungan oleh perusahaan semakin besar. 
Tabel 7 Debt Ratio PT SIA 2019-2020

\begin{tabular}{|l|r|r|}
\hline Keterangan & 2019 & 2020 \\
\hline Total Kewajiban & 2.024 .100 .000 & 2.700 .000 .000 \\
\hline Total Aset & 5.703 .741 .290 & 7.268 .397 .926 \\
\hline Debt Ratio & $35 \%$ & $37 \%$ \\
\hline
\end{tabular}

Sumber: Diolah dari Laporan Keuangan PT SIA

Pada perhitungan tabel 7 mengenai rasio utang terhadap aktiva PT SIA tahun 2019 sebesar 35\%, yang berarti bahwa seluruh aset yang dimiliki oleh PT SIA merupakan aset yang dibiayai kreditur sebesar $35 \%$ dan aset yang dibiayai dari modal perusahaan adalah sebesar $65 \%$. Pada tahun 2020, rasio utang terhadap aktiva PT SIA sebesar 37\%, yang berarti bahwa seluruh aset yang dimiliki oleh PT SIA merupakan aset yang dibiayai kreditur sebesar $37 \%$ dan aset yang dibiayai dari modal perusahaan adalah sebesar 63\%. Berdasarkan analisis data di atas, rasio utang terhadap aktiva PT SIA mengalami kenaikan sebesar $2 \%$ yaitu sebesar $35 \%$ pada tahun 2019 menjadi 37\% pada tahun 2020. Kenaikan ini berarti tidak baik untuk PT SIA karena proporsi utang terhadap aset (aktiva) dan ekuitas perusahaan semakin meningkat. Jika kedepannya terus naik dikhawatirkan PT SIA akan kesulitan untuk membayar utangnya.

Rasio Utang terhadap Modal Sendiri (Debt to Equity Ratio)

Dalam menganalisis utang terhadap modal sendiri pada PT SIA menggunakan perhitungan total kewajiban dibagi dengan ekuitas. Pada analisis rasio ini dapat mengukur jumlah modal PT SIA yang digunakan sebagai jaminan utang.

Tabel 8 Debt to Equity Ratio PT SIA 2019-2020

\begin{tabular}{|l|r|rr|}
\hline Keterangan & 2019 & 2020 \\
\hline Total Kewajiban & 5.703 .741 .290 & 7.268 .397 .926 & \\
\hline Ekuitas & 3.679 .641 .290 & 4.568 .397 .926 & \\
\hline Debt to Equity Ratio & $155 \%$ & & $159 \%$ \\
\hline
\end{tabular}

Sumber: Diolah dari Laporan Keuangan PT SIA

Pada tabel 8, rasio utang terhadap modal sendiri PT SIA tahun 2019 sebesar 155\%, yang berarti bahwa setiap Rp1 pendanaan melalui ekuitas maka perusahaan juga melakukan pendanaan melalui utang sebesar Rp1,55 atau bisa juga diartikan total utang yang dimiliki perusahaan dijaminkan dengan ekuitas perusahaan sebesar 155\%. Pada tahun 2020, rasio utang terhadap modal sendiri PT SIA sebesar 159\%, yang berarti bahwa setiap Rp1 pendanaan melalui ekuitas maka perusahaan juga melakukan pendanaan melalui utang sebesar Rp1,59 atau bisa juga diartikan total utang yang dimiliki perusahaan dijaminkan dengan ekuitas perusahaan sebesar $159 \%$. Secara keseluruhan, rasio utang terhadap modal sendiri PT SIA dinilai kurang baik oleh kreditur karena berada di atas nilai 100\%, yang artinya pendanaan didominasi dengan utang. Peningkatan atas rasio ini dapat berdampak buruk karena proporsi utang terhadap ekuitas akan meningkat sehingga di kemudian hari PT SIA dikhawatirkan tidak bisa membayar utangnya. Selain itu tidak sehat bagi perusahaan untuk mengandalkan sebagian pendanaannya pada utang.

\section{Analisis Rasio Profitabilitas Tahun 2019 dan 2020}

Margin Laba Kotor (Gross Profit Margin)

Dalam menganalisis margin laba kotor pada PT SIA menggunakan perhitungan laba kotor dibagi dengan penjualan bersih. Laba kotor didapat dari penjualan bersih dikurangi dengan HPP/COGS. Pada analisis rasio ini dapat mengukur kemampuan PT SIA dalam memenuhi atau membayar utang lancar yang akan jatuh tempo tanpa memperhitungkan nilai persediaan. 
Tabel 9 Gross Profit Margin PT SIA 2019-2020

\begin{tabular}{|c|c|c|}
\hline Keterangan & 2019 & 2020 \\
\hline Penjualan Bersih-HPP & 2.215 .755 .838 & 3.225 .395 .876 \\
\hline Penjualan Bersih & 5.295 .464 .521 & 8.974 .326 .776 \\
\hline Gross Profit Margin & $42 \%$ & $36 \%$ \\
\hline
\end{tabular}

Sumber: Diolah dari Laporan Keuangan PT SIA

Pada tabel 9, margin laba kotor PT SIA tahun 2019 sebesar 42\% dan mengalami penurunan sebesar 6\% pada tahun 2020 menjadi 36\%. Hal ini berarti kemampuan PT SIA dalam menghasilkan laba juga menurun dan dapat mengakibatkan tambahan saldo laba (retained earning) pada perusahaan turun atau tidak bertambah. Apabila penurunan ini terus terjadi kedepannya PT SIA akan mendapatkan penilaian yang buruk.

Margin Laba Bersih (Net Profit Margin)

Dalam menganalisis margin laba bersih pada PT SIA menggunakan perhitungan laba bersih lalu dibagi dengan penjualan bersih. Pada analisis rasio ini dapat mengukur kemampuan PT SIA dalam mengendalikan biaya dan pengeluaran terkait penjualan. Semakin tingginya margin laba bersih maka semakin produktif kinerja perusahaan dan akan meningkatkan kepercayaan investor untuk menanamkan modalnya.

Tabel 10 Net Profit Margin PT SIA 2019-2020

\begin{tabular}{|c|c|c|}
\hline Keterangan & 2019 & 2020 \\
\hline Laba Bersih & 462.615 .633 & 888.756 .636 \\
\hline Penjualan Bersih (EAIT) & 5.295 .464 .521 & 8.974 .326 .776 \\
\hline Net Profit Margin & $9 \%$ & $10 \%$ \\
\hline
\end{tabular}

Sumber: Diolah dari Laporan Keuangan PT SIA

Dari perhitungan tabel 10, margin laba bersih PT SIA tahun 2019 sebesar 9\%, yang berarti bahwa setiap Rp1 aset yang dimiliki perusahaan dapat menghasilkan laba bersih sebesar Rp0,09. Pada tahun 2020, margin laba bersih PT SIA sebesar 10\%, yang berarti bahwa setiap Rp1 aset yang dimiliki perusahaan dapat menghasilkan laba bersih sebesar Rp0,10. Margin laba bersih PT SIA mengalami kenaikan sebesar 1\% yaitu pada tahun 2019 sebesar 9\% dan tahun 2020 menjadi 10\%. Hal ini menunjukan bahwa PT SIA dapat menghasilkan laba bersih dengan lebih baik dari tahun lalu, tetapi apabila dibandingkan dengan margin laba kotor yang sudah dihitung di atas memiliki hasil yang berbanding terbalik. Seharusnya jika margin laba kotor naik maka margin laba bersih juga ikut naik. Penyebab hasil yang berbanding terbalik ialah tingginya beban usaha pada tahun 2020 yang tidak sebanding dengan laba kotornya sehingga laba kotor mengalami penurunan.

Tingkat Pengembalian Modal (Return on Equity)

Dalam menganalisis tingkat pengembalian modal pada PT SIA menggunakan perhitungan laba bersih dibagi dengan modal saham/ekuitas. Pada analisis rasio ini dapat mengukur keberhasilan PT SIA dalam menghasilakan laba rugi untuk para stake holder (pemegang saham). Semakin tinggi tingkat pengembalian modal maka dividen yang diperoleh stake holder juga semakin tinggi. Hal ini disebabkan kepemilikan perusahaan semakin kuat didukung dengan kenaikan tingkat pengembalian yang menyebabkan kenaikan saham.

Tabel 11 Return on Equity PT SIA 2019-2020

\begin{tabular}{|l|r|rl|}
\hline Keterangan & \multicolumn{2}{|c|}{2019} & 2020 \\
\hline Laba Bersih & 462.615 .633 & 888.756 .636 & \\
\hline Modal Saham (Ekuitas) & 3.679 .641 .290 & 4.568 .397 .926 & \\
\hline Return on Equity (ROE) & $13 \%$ & & $19 \%$ \\
\hline
\end{tabular}

Sumber: Diolah dari Laporan Keuangan PT SIA 


\section{JURNALKU}

Volume 1 No. 1, Maret 2021

Dari tabel 11, tingkat pengembalian modal PT SIA tahun 2019 sebesar 13\%, yang berarti bahwa setiap Rp1 total modal sendiri yang dimiliki, perusahaan dapat menghasilkan laba bersih sebesar Rp0,13. Pada tahun 2020, tingkat pengembalian modal mengalami kenaikan sebesar $6 \%$ yaitu menjadi 19\%. Hal ini berarti bahwa setiap Rp1 total modal sendiri yang dimiliki, perusahaan dapat menghasilkan laba bersih sebesar Rp0,19. Dari analisis di atas, PT SIA mengalami peningkatan nilai tingkat pengembalian modalnya yang berarti meningkatnya perusahaan pada efisiensi dalam menciptakan keuntungan dengan ekuitasnya.

\section{Dampak Pandemi COVID-19 pada Kinerja Keuangan PT SIA}

Bisnis perusahaan dapat tekena dampak buruk oleh efek dari wabah global penyakit menular, termasuk wabah baru-baru ini COVID 19 penyakit pernapasan yang dapat merugikan perekonomian di banyak negara, termasuk Indonesia. Stimulus keuangan diumumkan oleh berbagai negara yang diharapkan dapat memberikan dampak positif. Salah satu bisnis perusahaan yang bergerak di kontraktor mekanikal dan elektrikal yang terdampak ialah PT SIA. Berdasarkan wawancara yang dilakukan dengan Mbak Heni Widayanti yang bertanggung jawab atas penyusunan laporan keuangan PT SIA, mendapat informasi bahwa banyak sekali proyek atau lelang yang batal karena adanya pandemi COVID-19.

Dampak COVID-19 pada PT SIA dapat terlihat dari analisis rasio di atas yaitu pada penurunan dan peningkatan rasio. Perusahaan mengalami beberapa penurunan khususnya pada rasio lancar, rasio cepat, rasio kas, gross profit margin, dan net profit margin. Selain itu PT SIA juga mengalami kenaikan pada rasio perpuraran kas, rasio utang terhadap aktiva, rasio utang terhadap modal sendiri, margin laba bersih, dan return on equity. Pada rasio likuiditas PT SIA yang mengalami penurunan ialah rasio lancar, rasio cepat, dan rasio kas yang menunjukan perusahaan mengalami penurunan kemampuan dalam memenuhi utang/kewajibannya. Selain itu, rasio perputaran kasnya memiliki hasil yang berbanding terbalik dengan rasio kas perusahaan yang disebakan oleh meningkatnya pendapatan yang dimasukkan pada laporan laba rugi yang berasal dari penyelesaian proyek yang dikerjakan pada tahun lalu.

Pada rasio solvabilitas PT SIA mengalami peningkatan pada rasio utang terhadap aktiva dan rasio utang terhadap modal sendiri. Hal ini berarti jumlah modal pinjaman yang digunakan perusahaan mengalami peningkatan seiring pendanaan yang dilakukan PT SIA lebih banyak menggunakan pendanaan melaui utang. Semakin meningkatnya rasio solvabilitas maka berdampak buruk bagi perusahaan yaitu PT SIA dikhawatirkan tidak bisa membayar utangnya dikemudian hari. Pada rasio profitabilitas PT SIA mengalami kenaikan pada rasio margin laba bersih dan tingkat pengembalian modal yang berarti dengan adanya pandemi COVID-19 PT SIA masih mampu menghasilkan laba. Sedangkan pada margin laba kotor mengalami penurunan yang menyebabkan perusahaan akan mengalami kesulitan dalam memenuhi atau membayar utang lancar tanpa adanya persediaan yang ada. Secara keseluruhan, hasil perhitungan dari rasio likuiditas, rasio solvabilitas, dan rasio profitabilitas mencerminkan kerugian yang dialami PT SIA pada saat pandemi COVID-19 pada tahun 2020. PT SIA juga masih harus membayar utang yang dimiliki pada tahun 2020.

\section{Faktor Internal dan Eksternal yang mempengaruhi Kinerja Keuangan PT SIA}

Perubahan pada kinerja keuangan PT SIA juga disebabkan dari faktor internal dan eksternal. Berikut beberapa faktor internal dan eksternal yang didapat setelah melakukan wawancara dengan Yeti Widyawati, yang disapa dengan Mbak Yeti yang bertanggung jawab membuat laporan keuangan PT SIA. Faktor internal, yaitu (1) Keterlambatan pembuatan proyek karena adanya kebijakan baru yang mengakibatkan pegawai tidak dapat bekerja secara optimal seperti biasanya akibat adanya COVID-19. Hal ini menjadikan kontraktor mengalami keterlambatan dalam menyelesaikan proyek sesuai dengan waktu yang disepakati atau tercantum pada kontrak (Bahtiyar, 2012). (2) Penyusunan laporan keuangan kadang masih menggunakan pencatatan manual yang bisa jadi ada beberapa transaksi kecil yang tertinggal 


\section{JURNALKU}

Volume 1 No. 1, Maret 2021

untuk di masukan pada laporan final (belum terintregasi menjadi satu). Hal ini dapat memicu timbulnya bias pada pelaporannya. (3) Perhitungan biaya depresiasi yang belum sesuai dengan ketentuan, seperti biaya yang menambah masa manfaat (capital expenditure) yang harusnya dikapitalisasi tetapi di masukan kedalam beban operasional.

Faktor eksternal, yaitu (1) Pembatalan proyek dari klien yang tidak dapat diprediksi oleh PT SIA. (2) Lelang proyek yang sulit didapatkan karena banyak perusahaan pesaing dan kondisi pasar yang sedang lesu akibat adanya pandemi COVID-19, sehingga para peruahaan kontraktor sulit mendapatkan proyek baru sesuai dengan yang diungkapkan wirawan tahun 2020. (3) Pandemi COVID-19 yang secara tidak langsung mempengaruhi pengeluaran perusahaan (biaya tak terduga) dalam menjalankan protokol kesehatan untuk semua pegawainya dalam rangka memutus penyebaran rantai penularan COVID-19.

\section{Upaya Perbaikan PT SIA terhadap Pandemi COVID-19}

Pihak manajemen selalu mencari langkah perbaikan dalam kinerja keuangan serta strategi untuk menghadapi COVID-19 yang tengah mewabah ini. Pandemi COVID-19 juga memiliki pengaruh besar dalam kegiatan usaha yang dilakukan PT SIA. Hal ini dilakukan agar usaha dan kegiatan operasi tetap berjalan, berikut beberapa tindakan yang diambil manajemen dalam menghadapi pandemi COVID-19 berdasarkan hasil wawancara, yaitu (1) Melakukan perombakan dan penyusunan ulang biaya estimasi untuk kegiatan operasi sehingga dapat mencapai target. (2) Menyiapkan pegawai agar selalu mematuhi protokol kesehatan sehingga proyek tetap berjalan dan pegawai dapat terhindar dari penyakit COVID-19. (3) Memulai untuk menyatukan data pada satu catatan agar data dapat terintegrasi dan tidak ada kesalahan input maupun catatan yang tertinggal. Sehingga tidak ada salah perhitungan pada laporan keuangan kedepannya. (4) Pihak manajemen sekarang mulai untuk membuat estimasi pada dana cadangan darurat untuk menghadapi ketidakpastian kedepannya.

\section{PENUTUP}

Secara likuiditas PT SIA mengalami degradasi dari tahun 2019 ke tahun 2020 yaitu penurunan pada rasio lancar, rasio cepat, dan rasio kas. Hal ini membuktikan bahwa PT SIA secara tidak langsung terdampak oleh kondisi COVID-19, meskipun dampak yang dihasilkan tidak begitu signifikan tetapi hasil analisis menunjukan adanya penurunan kualitas kinerja PT SIA dalam likuiditasnya. Setelah itu, Secara solvabilitas dapat dilihat bahwa PT SIA mengalami peningkatan pada rasio utang terhadap aktiva dan rasio utang terhadap modal sendiri yang berarti dengan adanya COVID-19, PT SIA menghadapi penurunan dalam menjamin utangnya menggunakan modalnya sendiri maupun ekuitasnya. Terakhir kondisi profitabilitas PT SIA dapat dikatakan baik dan masih mampu menghasilkan laba pada saat pandemi COVID-19. Hal ini menunjukan tindakan manajemen yang diambil PT SIA sudah baik.

Faktor internal dan eksternal juga mempengaruhi kinerja keuangan PT SIA selain dari adanya pandemi COVID-19. Manajemen juga selalu melakukan upaya perbaikan seperti menyusun ulang strategi dan perombakan estimasi biaya dalam mengelola kegiatan operasinya agar selalu dapat beroperasi.

\section{DAFTAR PUSTAKA}

Ardiyos. (2008). Kamus Besar Akuntansi. Jakarta : Citra Harta Prima

Azizah, A. (2015). Analisis Kinerja Keuangan Perusahaan (Perbandingan Penggunaan Analisis Rasio Keuangan Dan Du Pont System)(Studi Pada PT. Unilever Indonesia, Tbk Dan Anak Perusahaan Yang Terdaftar Di Bursa Efek Indonesia Periode 2007-2013). Administrasi Bisnis, 1-7.

Dewa, A. P., \& Sitohang, S. (2015). Analisis kinerja keuangan PT Indofood Sukses Makmur tbk di bursa efek indonesia. Jurnal Ilmu dan Riset Manajemen (JIRM), 4(3). 


\section{JURNALKU}

Volume 1 No. 1, Maret 2021

Fahmi, I. (2012). Analisis Kinerja Keuangan. Bandung: Alfabeta

Gani, R., \& Putri, N. M. (2018). Analisis Kinerja Keuangan PT. Indofood Sukses Makmur Tbk DI Bursa Efek Indonesia. Gorontalo Management Research, 1(2), 53-66.

Harjito, A., \& Martono. (2011). Manajemen Keuangan, Edisi Kedua, Cetakan Pertama. Yogyakarta : Penerbit EKONISIA,

Harahap, S. S. (2010) .Analisa Kritis atas Laporan Keuangan. Cet 11. Jakarta : PT Raja Grafindo Persada

Ikatan Akuntansi Indonesia (2012), Standar Akuntansi Keuangan. Jakarta : Salemba Empat.

Jumingan. (2009). Analisis Laporan Keuangan. Bumi Aksara, Surakarta.

Kasmir. (2014). Analisis Laporan Keuangan, cetakan ke-7. Jakarta: PT Raja Grafindo Persada

Kieso, D. E., Weygandt, J. J., Warfield, T. D., Wiecek, I. M., \& McConomy, B. J. (2019). Intermediate Accounting, Volume 2. John Wiley \& Sons.

Maith, H. A. (2013). Analisis Laporan Keuangan Dalam Mengukur Kinerja Keuangan Pada PT. Hanjaya Sampoerna Tbk. EMBA, 621-627.

Mulyadi. (2009). Akuntansi Biaya. Yogyakarta : STIE YPKPN

Munawir. (2010). Analisa Laporan Keuangan, cetakan ke-15. Yogyakarta: Liberty Yogyakarta

Pratiwi, A. A., Sondakh, J. J., \& Kalangi, L. (2014). Analisis penerapan SAK ETAP pada penyajian laporan keuangan PT. Nichindo Manado Suisan. Jurnal EMBA: Jurnal Riset Ekonomi, Manajemen, Bisnis dan Akuntansi, 2(3).

Rudiantoro, R., \& Siregar, S. V. (2012). Kualitas laporan keuangan umkm serta prospek implementasi SAK ETAP. Jurnal Akuntansi dan Keuangan Indonesia, 9(1), 1-21.

Santoso, K. J., Wijaya, K. A., \& Chandra, H. P. (2021). Potret Industri Konstruksi di Surabaya dalam masa Pandemi Covid-19. Jurnal Dimensi Pratama Teknik Sipil, 10(1), 57-64.

Siagian, R. P., \& Pangemanan, S. S. (2016). Analisis Penyajian Laporan Keuangan Berdasarkan SAK-ETAP Pada Koperasi Karyawan Bank Sulut Go. Jurnal EMBA: Jurnal Riset Ekonomi, Manajemen, Bisnis dan Akuntansi, 4(1).

Shanjaya, A. R., \& Marlius, D. (2017). Peranan Laporan Keuangan Dalam Kebijaksanaan Pemberian Kredit Kepada Calon Nasabah Pada PT. BPR Batang Kapas. Akademi Keuangan dan Perbankan Padang, 1-10.

Subramanyam, K. R dan John J. Wild (2010). Analisis Laporan Keuangan. Edisi 10.Jakarta: Salemba Empat.

Surya Inti Abadi. (2019). Laporan Auditor Independen dan Laporan Keuangan Per 31 Desember 2019. Ponorogo: PT SIA.

Surya Inti Abadi. (2020). Laporan Auditor Independen dan Laporan Keuangan Per 31 Desember 2020. Ponorogo: PT SIA.

Tumelap, J. (2011). Analisis Kinerja Perusahaan Jasa Pelaksana Konstruksi (Studi Kasus di Kabupaten Sarmi). 137.

Wuwungan, J. Y. (2016). Analisis penerapan standar akuntansi keuangan entitas tanpa akuntabilitas publik atas persediaan pada apotik uno medika. Jurnal EMBA: Jurnal Riset Ekonomi, Manajemen, Bisnis dan Akuntansi, 3(4). 